\title{
Phonological study of the Sonaha language ${ }^{1}$
}

\begin{abstract}
Anil Dutt Chaudhary
Abstract

The Sonaha is a language which is spoken in Bardiya, Kailali and Kanchanpur districts in Nepal. Sonaha language, henceforth Sonaha, was not identified by the government before the Census 2011. In spite of having its own linguistic features and originality, Sonaha is badly affected by the influence of other neighbouring languages. Keeping this in mind, this study mainly aims to explore and present the inventory of the phoneme, syllable structures and vowel sequence or, in short, to highlight the phonological system of Sonaha language. Sonaha 3404 native words were collected from fifty native speakers of Rajapur Municpality and Geruwa Rural Municplaity of Bardiya district, Ghodaghodi Municipality of Kailali and Bhimdutt Municiplaity of Kanchanpur district. The data were presented and analyzed based on minimal pairs to verify phonemes. This study explored six vowels, twenty nine consonants, six types of syllable structures and seven vowel sequences in Sonaha.
\end{abstract}

Key words: Consonant cluster; Minimal pairs; Phoneme; Sonaha; Syllable structure

\section{Introduction}

The census of Nepal 2001 enumerated 92 living languages (spoken and signed) in use among the 103 caste and ethnic groups of the nation, whereas the census 2011 listed 123 languages in Nepal (spoken and sign). Many languages of Nepal are spoken by ethnic groups of people. Sonaha language is one of them which is spoken by Sonaha indigenous people. This is an endangered language according to the list of Language Commission Nepal. The name of the language is derived from the name of the community's tribe. The alternative name of this language is Sonha, Sonaha, Sonahaa,

\footnotetext{
${ }^{1}$ Cite this article as: Chaudhary, A.D. (2020). Contemporary Research: An Interdisciplinary Academic Journal, vol. 4 (1)

Anil Dutt Chaudhary, Lecturer, Amar Shahid Multiple Campus, Bardiya, Nepal. Email: chaudharyanildutt@gmail.com Article history: Received on September 18; Accepted on October 22; Published on October 30 Peer reviewed under the authority of CRAIAJ, academic journal of Ghodaghodi Multiple Campus, Kailali, Nepal, with ISSN 2717-4611 (Print) and ISSN 2717-462X (Online).

(C) 2020 CRAIAJ
}

Full text of this article can be downloaded from www.craiaj.com and www.nepjol.info 
Sunah, Sunha (Epple, Lewis, Regmi \&Yadav eds., 2012). However, the elder Sonaha people claim it as 'Sunaha' (Sonaha, 2018). According to Ethnologue Language of the World, the ISO code of this language is 639-3 (soi). The Expanded Graded International Disruption Scale (EGIDS) status of this language is defined under 7 Level, i.e. shifting level.The EGIDS is a multi-dimensional scale which focuses on different aspects of vitality at different levels of the scale. The EGIDS level of this language is meant the people bearing generation of this ethnic group know the language well enough to use it among themselves but it is not being transmitted to their children (Epple, Lewis, Regmi \& Yadav eds., 2012).

This language is mainly spoken in Daulatpur, Murgahawa, Himalipur, Chanaura, Manparipur, Sarkhol, Rajipur, Sankatti and Prasehani (Saijanatol) in Bardiya district; Bhajani, Munuwa, Gorange in Kailali district and Adali, Airi, Pipariya and Bhujela in Kanchanpur district. The population of Sonaha people has not been identified by the Census 2011. The Sonaha leaders claim that they were merged in Tharu population. The total number of Sonaha is 1172 (Sonaha, 2018). The average household (HH) sizes for Bardiya, Kailali and Kanchanpur are 5.13, 5.44 and 5.59 as per the National Population and Housing Census 2011respectively. Thing (2014) calculated 238 Sonaha's houses in those districts. As per the average household sizes in those districts, he calculated 1249.09 as the total number of Sonaha's population. The Census 2011 only shows the total number of Sonaha mother tongue speakers, i.e. 579. However, the $60 \%$ male and $33 \%$ female of Sonaha can read and write their mother tongue (Thakur\&Thakur, 2014).

There are few numbers of written documents about Sonaha regarding its genetic relationship. It has been categorized under the Indo-European family of IndoIranian, Indo-Aryan, Central zone (Epple, Lewis, Regmi \&Yadav eds., 2012). But Eberhard, Gary \& Charles (2019) have kept it under Western zone, unclassified. However, the influences of the other neighbouring languages such as Dagaura Tharu with $80 \%$ intelligibility, lexical similarity: $69 \%$ with Rana Tharu, $73 \%$ with Kathariya Tharu, 72\% with Dangaura Tharu (Epple, Lewis, Regmi \&Yadav eds., 2012) also proves that this language belongs to the same family of the above language. The dialect of this language is not confirmed (Epple, Lewis, Regmi \&Yadav eds., 2012). Based on the survey conducted by Chaudhary, Chaudhary and Khanal (2018b) confirmed 'Bhauraihya' and 'Kanchanpurihya' as dialects of Sonaha. 


\section{Review of literature}

Phonology studies the sound systems of languages (Crystal, 2008), and it is concerned with speech sounds forming patterns in a particular language (Gut, 2009). However, Carr (2013) explains it as the study of certain sorts of mental organization, not the study of human speech sounds per se. The main aim of phonology is to demonstrate the pattern of distinctive sound found in a specific language, to make as general statement as possible about the nature of the sound system of the world (Crystal, 2008), and to establish phonemes (Roach, 2013). Phoneme is a part of phonology, and viewed as the smallest unit of sound system. Roach (2013) simplified it as a number of regularly used sounds.

There have been numerous studies to investigate about the phoneme of different languages. Lohar (2008) in his study of sound system of Bhojpuri language has illustrated and analyzed consonant and vowel sounds through different perspectives. He claims that Bhojpuri language being written in Devanagari script has the alphabets almost correspond to the phonemes of Devanagari script. However, he indicated that it is difficult to separate the diphthong vowel of that language. Likewise, Chaudhary (2013) has explained 28 consonants and six vowel sounds in Saptariya Tharu language. Similarly, the joint study done on Mid-Eastern Tharu language by SIL International and Matribhasha Sewa Kendra in 12 districts in eastern parts of Nepal has proposed 30 consonants and eight vowel sounds (as cited in, Chaudhary, 2020). Both the studies have included dental consonants /t, t, d, d / which are also found in Sonaha language. However, Boehm (2003) found that there is the absence of dental plosive series in Dangaura Tharu. He looked at the phonemic inventory, the distribution of phonemes, syllable types, stress and phonological process in this Tharu variety and concluded that there are 31 consonants, eight vowels including two diphthongs. He also found six types of syllable patterns, however, concluded that there are minimal consonant clusters in the onset, and no consonant clusters permitted in coda. Since Sonaha language is very much close to Dangaura Tharu phonologically, lexically or semantically, it seems different from Dangaurain dental phonemes. The study on "Dangaura Tharu Bhashako Varna Nirdharn" done by National Foundation for Development of Indigenous Nationalities (2020) in Dang district has proposed 30 consonants and 16 vowels in Dangaura Tharu. The proposed Dangaura Tharu aspirated breathy nasal sounds such /m , n , y /, aspirated lateral / / and aspirated trill $/ \mathrm{r} /$ are also found in Sonaha except $/ \mathrm{g} /$. Dhakal (2013) has 
determined 33 consonants such as $/ \mathrm{k}, \mathrm{k}, \mathrm{g}, \mathrm{g}, \mathrm{y}$, ts, ts , dz, dz, , , , , t, t , d, d , $\mathrm{n}, \mathrm{n}, \mathrm{p}, \mathrm{p}, \mathrm{b}, \mathrm{b}, \mathrm{m}, \mathrm{m}, \mathrm{j}, \mathrm{r}, \mathrm{r}, \mathrm{l}, \mathrm{l}, \mathrm{w}, \mathrm{s}$ and h/ and six vowels such as / , , i, u, e, o/ in Rana Tharu language. These are the exact consonants and vowels which are also found in Sonaha language, however, the aspirated breathy sounds /m, n, $\mathrm{r}$ and 1 / still need to be confirmed. My study is very much similar to these studies in regarding methodology because almost all the studies have employed the use of minimal pair to determine the phonemes.

Webster (1993) claimed that Sunha (SkP) and Kathoriya (KkP) do not fit easily in any of the other subgroups of Tharu languages. Sunha shares 70 percent or greater lexical similarity with the Rana group and 72 percent or greater with the Dangora group. Both Sunha and Kathoriya seem to form bridges between the Rana and Dangaura. Similarly, Epple, Lewis, Regmi \&Yadav eds. (2012) has explained that Sonaha language has $80 \%$ intelligibility with Dangaura Tharu (thl) and Awadhi (awa). It has $69 \%$ lexical similarity with Rana Tharu (thr), $73 \%$ with Kathariya (tkt) and $72 \%$ with Dagaura Tharu.

Apart from language, the previous researches showed that there is no unanimous view regarding the origin of Sonaha. Sonaha (2000) justified how Sonaha became Sonaha from Jalthakuri, but the study conducted by Budha (2006) proved the confusion of their origin. Similarly Chaudhary, Chaudhary and Khanal (2019) found that Sonaha are still unknown about their generic origin, and from where and when they came to the lower Karnali river delta is a subject of study.

Likewise, seminal contributions have been made by Adhikari (2009), G.C. (2012), Thing (2014), Chaudhary (2015) and Sonaha (2018), Chaudhary, Chaudhary and Khanal (2019) to study about Sonaha's socio-cultural, educational, health and economic conditions. They have commonly concluded for preserving them as their suggestions.

Goshain (2013) compared Sonaha verbs related to harvesting and wedding ceremony with Nepali and English verb. He limited study to the comparison of morpho-syntax only. He found that the English language has less number of preharvesting and harvesting, pre-wedding and wedding verbs in comparison to Nepali and Sonaha, and Nepali has the largest in comparison to Sonaha and English. Thakur and Thakur (2014) surveyed the linguistic and sociolinguistic background information about the Sonaha and Khuna language. They found that all the members of Sonaha and Khuna communities are very much fluent in speaking their mother 
tongues, whereas only a few literate Sonaha and Khuna speakers are good in reading and writing their languages. Sonaha language spoken in Bardiya district is very much similar to Sonaha spoken in Kanchanpur district, i.e. $76 \%$ similarity is seen between the two varieties of Sonaha lexical items. Chaudhary, Chaudhary and Khanal (2018b) collected Sonaha word preparing the ontology of different domains of language. They conducted a survey, and collected altogether 3304 words from different domains of language.

These works so far reviewed have assisted the understanding of the existing Sonaha socio-culture, origin and their features of language. However, very few works have been done regarding Sonaha and its linguistic features. Some works, though with limited data, are of descriptive types. However, no attempt has yet been made to study the phonological analysis of Sonaha from the Sonaha's area. Thus, for a detailed description in Sonaha, each domains of the language has to be further explored with more discourse data.

\section{Methodology}

This study was based on the mixed method design with cross sectional survey. Fifty Sonaha native speakers from Bardiya, Kailali and Kanchanpur districts were purposively selected. The lists of ontology from different domains of Sonaha language was prepared, and asked to the informants to collect the words as per the ontologies at the time of field observation. Some lexical items were also obtained directly from the formal and informal interviews. A list of Tharu and Nepali words was prepared and asked the Sonaha native speakers to translate those words in their language too. Some translated written texts in Sonaha language were also used to gather the words. The collected data were presented in the table and analyzed using minimal pair both phonologically and morphologically. The phonemes were verified individually and in groups.

\section{Results and discussion}

This paper mainly focuses on phonology of Sonaha. To determine its phonemes in clear concise way, morphological aspect was considered to be the base. The findings of the study are presented as follows.

\section{Vowel phonemes}

Sonaha language has six vowel phonemes. In terms of height of the tongue, there are two high vowels /i/ and /u/, two mid vowels /e/ and /o/, and two low vowels /ə/ and 
/a/. Likewise, on the basis of the part of the tongue there are three front vowels /i/, /e/ and $/ \mathrm{a} /$, a single central vowel $/ \mathrm{N}$, and two back vowels $/ \mathrm{u} / \mathrm{and} / \mathrm{o} / \mathrm{I}$ In the same way, in terms of position of the lips, there are rounded $/ \mathrm{u} / \mathrm{and} / \mathrm{o} /$ and four unrounded vowels $/ \mathrm{i} /, \mathrm{e} / \mathrm{e} / \mathrm{N} /$ and $/ \mathrm{a} /$. The high and mid vowels differ in terms of back part of the tongue: high front vowel /i/ and high back vowel /u/ and mid front vowel /e/ and mid back vowels /o/ while the low vowels $/ \mathrm{L} /$ and front low vowel /a/ are both roughly central. The nasalization is contrastive in some places but the distribution is not even. The length feature in vowels seems to occur phonetically but not identified well. These vowels are shown in Figure 1 according to the cardinal vowel system.

Front central back

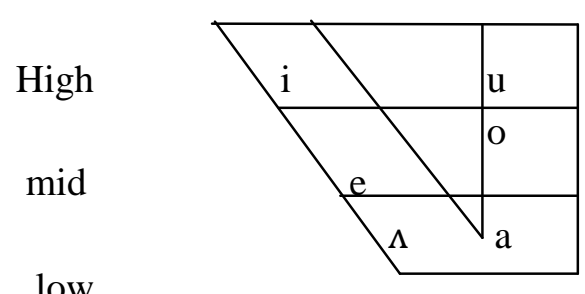

Figure1. Sonaha cardinal vowels

\section{Minimal pairs to determine vowel phonemes}

Minimal pairs are the pairs of words, may be written and spoken, that are different in only one phonological element such as phoneme. Generally, minimal pairs of words are used to recognize the phoneme of a particular language. Some minimal pairs of Sonaha words are presented below to determine vowel.

\begin{tabular}{|c|c|c|}
\hline /u/ vs /o/ & us-kıina & 'to uplift clothes' \\
\hline & os-knina & $\begin{array}{l}\text { 'to turn over straw while } \\
\text { threshing' }\end{array}$ \\
\hline \multicolumn{3}{|c|}{ Rounded vs unrounded. } \\
\hline$/ \mathrm{u} / \mathrm{vs} / \Lambda /$ & ui-yã & 'a kind of grass' \\
\hline & $\Lambda \mathrm{i}-\mathrm{ya}$ & $\begin{array}{l}\text { 'eep! A word used by the } \\
\text { Sonaha women while } \\
\text { feeling pain or surprise' }\end{array}$ \\
\hline /u/ vs /i/ & u-par & 'across the river' \\
\hline
\end{tabular}




$\begin{array}{ll} & \text { i-par } \\ \text { /o/ vs /e/ } & \mathrm{dz}^{\mathrm{h}} \mathrm{o}-\mathrm{kna} \\ & \mathrm{dz} \text { e-lna } \\ \text { /u/vs /a/ } & \text { ute } \\ & \text { ate }\end{array}$

Unrounded vs unrounded.

\begin{tabular}{|c|c|}
\hline /a/ vs /i/ & $\begin{array}{l}\operatorname{ur} \Lambda \mathrm{i}-\mathrm{na} \\
\operatorname{ur} \Delta \mathrm{i}-\mathrm{ni}\end{array}$ \\
\hline / $/$ vs /i/ & $\Lambda \eta$-gur \\
\hline /a/ vs /e/ & $\begin{array}{l}\text { uhi-ma } \\
\text { uhi-se }\end{array}$ \\
\hline /e/ vs /i/ & a-ge \\
\hline & $a-g$ \\
\hline$/ \mathrm{a} / \mathrm{vs} / \mathrm{\Lambda} /$ & a-dza \\
\hline & $a-d z$ \\
\hline /e/ vs / $/$ & a-te \\
\hline & $a-m$ \\
\hline
\end{tabular}

High vs high.

/u/ vs /i/ u-par

Mid vs mid.

o/ vs /e/ $\quad \begin{aligned} & \mathrm{dz}^{\mathrm{h}} \mathrm{o}-\mathrm{kna} \\ & \mathrm{dz} \mathrm{h}^{\mathrm{h}} \mathrm{e}-\operatorname{lna}\end{aligned}$

Low vs low.

/a/ vs / $/$ /

$$
\text { a-dza }
$$$$
\text { a-dz }
$$

High vs mid.

$\begin{array}{ll}\text { /e/ vs /i/ } & \text { a-ge } \\ & \text { a-gi } \\ \text { /u/ vs /o/ } & \text { us-knina } \\ & \text { os-knina }\end{array}$

High vs low.

/N/ vs /i/ 'in your own side of the river'

'to spread salt on curry'

'to bear the problem'

'there, that side'

'to be'

'to fly'

'the main pole of the thacthed house'

'grapes'

'fingers'

'in that same thing'

'better than him/her/that'

'the east'

'the fire'

'grandfather,grandfather's

father'

'today'

'to be'

'mango'

'across the river'

'in your own side of the

river'

'to spread salt on curry'

'to bear the problem'

'grandfather, grandfather's

father'

'today'

'the east'

'the fire'

'to uplift clothes'

'to turn over straw while threshing'

'grapes'

Full text of this article can be downloaded from www.craiaj.com and www.nepjol.info 


\begin{tabular}{|c|c|c|}
\hline & in-guri & 'fingers' \\
\hline \multirow[t]{2}{*}{ /a/ vs /i/ } & ursi-na & 'to fly' \\
\hline & ur $\Lambda \mathrm{i}-\mathrm{ni}$ & $\begin{array}{l}\text { 'the main pole of the } \\
\text { thacthed house' }\end{array}$ \\
\hline \multirow[t]{2}{*}{$/ \mathrm{u} / \mathrm{vs} / \mathrm{N} /$} & ui-yã & 'a kind of grass' \\
\hline & $\Lambda \mathrm{i}-\mathrm{ya}$ & $\begin{array}{l}\text { 'eep! A word used by the } \\
\text { Sonahawomenwhile } \\
\text { feeling pain or surprise' }\end{array}$ \\
\hline \multirow[t]{2}{*}{ /u/ vs /a/ } & u-te & 'there' \\
\hline & a-te & 'to be' \\
\hline \multicolumn{3}{|c|}{ Mid vs low. } \\
\hline \multirow[t]{2}{*}{ /e/ vs / / } & a-te & 'to be' \\
\hline & $\mathrm{a}-\mathrm{m}$ & 'mango' \\
\hline \multirow[t]{2}{*}{ /a/ vs /e/ } & uhi-ma & 'in that same thing' \\
\hline & uhi-se & 'better than him/her/that' \\
\hline \multirow[t]{3}{*}{ /o/ vs /a/ } & kõ-ts & 'love birds' \\
\hline & kã-s & 'a very smooth grass used \\
\hline & & $\begin{array}{l}\text { to make a basket which is } \\
\text { used for carrying things } \\
\text { in it' }\end{array}$ \\
\hline
\end{tabular}

\section{Consonant phonemes}

Sonaha language has 29 consonants. They are bilabial, dental, alveolar and velar stops $/ \mathrm{p}, \mathrm{p}^{\mathrm{h}}, \mathrm{b}, \mathrm{b}^{\mathrm{h}}, \mathrm{t}, \mathrm{t}^{\mathrm{h}}, \mathrm{d}, \mathrm{d}^{\mathrm{h}}, \mathrm{t}, \mathrm{t}^{\mathrm{h}}, \mathrm{d}, \mathrm{d}^{\mathrm{h}}, \mathrm{k}, \mathrm{k}^{\mathrm{h}}, \mathrm{g}, \mathrm{g}^{\mathrm{h}} /$; alveolar and glottal fricatives $/ \mathrm{s}$, $\mathrm{h} /$; alveolar affricates $/ \mathrm{c}, \mathrm{c}^{\mathrm{h}}, \mathrm{dz}, \mathrm{dz} /$; bilabial, alveolar and velar nasals /m, n, y/; alveolar lateral /l/; alveolar trill /r/ and bilabial and palatal glides /w, y/. Aspiration is contrastive in stops and affricates. Unaspirated voiceless stops and affricates have their voiced counterparts whereas aspirated voiceless stops and affricates lack their voiced counterparts. Both the alveolar fricative /s/and glottal fricative /h/are voiceless. And nasals, lateral, trill and glides are voiced. Some voiced aspirated consonants such as / $\mathrm{m}^{\mathrm{h}}, \mathrm{n}^{\mathrm{h}}, \mathrm{l}^{\mathrm{h}}$ and $\mathrm{r}^{\mathrm{h}} /$ seem to occur, but not confirmed. They are not so productive but found in a few native words such as 'guim ${ }^{\mathrm{h}} \mathrm{a}$ ' (a kind of creeper having yellow fruit) 'p$\Lambda \mathrm{h} \Lambda \mathrm{rn}^{\mathrm{h}} \mathrm{a}$ ' (to read), 'kor ${ }^{\mathrm{h}} \mathrm{i}$ ' (lazy) and ' $\mathrm{p}^{\mathrm{h}}$ ill ${ }^{\mathrm{h}} \mathrm{a}^{\prime}$ (thigh). All the consonants except $/ \mathrm{m}^{\mathrm{h}}, \mathrm{n}^{\mathrm{h}}, \mathrm{l}^{\mathrm{h}}$ and $\mathrm{r}^{\mathrm{h}} /$ are found in written system. They seem to be the allophones of $/ \mathrm{m}, \mathrm{n}, \mathrm{r}$ and $1 /$ respectively. All the consonant phonemes are presented below.

Table 1: Sonaha consonants

Full text of this article can be downloaded from www.craiaj.com and www.nepjol.info 


\begin{tabular}{|c|c|c|c|c|c|c|}
\hline $\begin{array}{l}\text { Place of articulation } \rightarrow \\
\downarrow \text { Manner of articulation }\end{array}$ & Bilabial & Dental & Alveolar & Palatal & Velar & Glottal \\
\hline & $\mathrm{p} \quad \mathrm{b}$ & $\begin{array}{ll}\mathrm{t} & \mathrm{d}\end{array}$ & $\mathrm{td}$ & & $\begin{array}{ll}\mathrm{k} & \mathrm{g}\end{array}$ & \\
\hline Stops & $\mathrm{p}^{\mathrm{h}} \mathrm{b}^{\mathrm{h}}$ & $\mathrm{t}^{\mathrm{h}} \mathrm{d}^{\mathrm{h}}$ & $t^{h} d^{h}$ & & $\mathrm{k}^{\mathrm{h}} \mathrm{g}^{\mathrm{h}}$ & \\
\hline Fricatives & & & $\mathrm{s}$ & & & $\mathrm{h}$ \\
\hline Affricates & & & $\begin{array}{l}\mathrm{c} \quad \mathrm{dz} \\
\mathrm{c}^{\mathrm{h}} \mathrm{dz}^{\mathrm{h}}\end{array}$ & & & \\
\hline & $\mathrm{m}$ & & $\mathrm{n}$ & & & \\
\hline Nasals & $\left(\mathrm{m}^{\mathrm{h}}\right)$ & & $\left(\mathrm{n}^{\mathrm{h}}\right)$ & & & \\
\hline Lateral & & & $\begin{array}{c}1 \\
\left(\mathrm{l}^{\mathrm{h}}\right)\end{array}$ & & & \\
\hline Trill & & & $\begin{array}{c}\mathrm{r} \\
\left(\mathrm{r}^{\mathrm{h}}\right)\end{array}$ & & & \\
\hline Glides (approximant) & $\mathrm{w}$ & & & $\mathrm{y}$ & & \\
\hline
\end{tabular}

Minimal pair to determine consonants

Some minimal pairs of Sonaha words are presented below to confirm consonants.

Bilabial stops.

\begin{tabular}{|c|c|c|}
\hline \multirow[t]{2}{*}{$/ \mathrm{p} / \mathrm{vs} / \mathrm{p}^{\mathrm{h}} /$} & $\mathrm{p} \Lambda \mathrm{k}-\mathrm{na}$ & 'to be cooked' \\
\hline & $\mathrm{p}^{\mathrm{h}} \Lambda \mathrm{k}-\mathrm{na}$ & 'to throw' \\
\hline \multirow[t]{2}{*}{ /b/ vs / $\mathrm{b}^{\mathrm{h}} /$} & ba-te & 'folk tales' \\
\hline & $\mathrm{b}^{\mathrm{h}}$ at & 'rice’ \\
\hline \multicolumn{3}{|l|}{ Dental stops. } \\
\hline \multirow[t]{2}{*}{$/ \mathrm{t} / \mathrm{vs} / \mathrm{d} / \mathrm{tal}$} & & 'pond' \\
\hline & dal & 'cooked lentil' \\
\hline \multirow[t]{2}{*}{$/ \mathrm{t} / \mathrm{vs} / \mathrm{t}^{\mathrm{h}} / \mathrm{t} \Lambda \mathrm{p}-\mathrm{na}$} & & 'to make body warm, to bask' \\
\hline & $\mathrm{t}^{\mathrm{h}} \Lambda \mathrm{p}-\mathrm{na} /$ & 'to extend one's hand to receive something' \\
\hline \multirow[t]{2}{*}{$/ \mathrm{d} / \mathrm{vs} / \mathrm{d}^{\mathrm{h}} /$} & $\mathrm{d} \Lambda \mathrm{r}-\mathrm{na}$ & 'to give fodder to the cattle, to set' \\
\hline & $\mathrm{d}^{\mathrm{h}} \Delta \mathrm{r}-\mathrm{na}$ & 'to keep' \\
\hline \multicolumn{3}{|l|}{ Alveolar stops } \\
\hline \multirow[t]{2}{*}{$/ \mathrm{t} / \mathrm{vs} / \mathrm{d} / \mathrm{t} \Lambda \mathrm{s}-\mathrm{na}$} & & 'to stick, to patch' \\
\hline & des-na & 'a kind of thin blanket' \\
\hline \multirow[t]{2}{*}{$/ \mathrm{t} / \mathrm{vs} / \mathrm{t}^{\mathrm{h}} / \mathrm{tok}-\mathrm{ni}$} & & $\begin{array}{l}\text { 'a small open plain or colourful basket } \\
\text { made of special grasses' }\end{array}$ \\
\hline & $\mathrm{t}^{\mathrm{h}} \Lambda \mathrm{k}-\mathrm{ni}$ & $\begin{array}{l}\text { 'a kind of broom made of bamboo used for } \\
\text { combing hair' }\end{array}$ \\
\hline \multirow[t]{2}{*}{ /d/ vs / $\mathrm{d}^{\mathrm{h}} /$} & des-na & 'a kind of thin blanket' \\
\hline & $\mathrm{d}^{\mathrm{h}} \mathrm{es}-\mathrm{na}$ & 'to push' \\
\hline
\end{tabular}

Velar stops.

Full text of this article can be downloaded from www.craiaj.com and www.nepjol.info 


\begin{tabular}{|c|c|c|}
\hline$/ \mathrm{k} / \mathrm{vs} / \mathrm{k}^{\mathrm{h}} /$ & $\begin{array}{l}\text { ki-ra } \\
\mathrm{k}^{\mathrm{h}} \mathrm{i}-\mathrm{ra}\end{array}$ & $\begin{array}{l}\text { 'an insect' } \\
\text { 'a cucumber' }\end{array}$ \\
\hline \multirow[t]{2}{*}{$/ \mathrm{k} / \mathrm{vs} / \mathrm{g} / \mathrm{k} \Lambda \mathrm{l}-\mathrm{la}$} & & 'tip of the new plant' \\
\hline & gul-la & 'testes' \\
\hline \multirow[t]{2}{*}{$/ g / v s / g^{h} /$} & 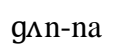 & 'sugarcane' \\
\hline & $g^{h} \Lambda n-n a$ & 'to wear' \\
\hline \multicolumn{3}{|c|}{ Alveolar fricative vs glottal fricative. } \\
\hline \multirow[t]{2}{*}{ /s/ vs /h/surna } & & 'to transfer' \\
\hline & $\mathrm{h} \wedge \mathrm{r}-\mathrm{na}$ & 'to lose bet' \\
\hline \multicolumn{3}{|c|}{ Alveolar affricatives } \\
\hline \multirow[t]{2}{*}{$/ \mathrm{c} / \mathrm{vs} / \mathrm{c}^{\mathrm{h}} /$} & cu-riya & 'bangles' \\
\hline & $\mathrm{c}^{\mathrm{h}} \mathrm{u}$-riya & 'a knife' \\
\hline \multirow[t]{2}{*}{$/ \mathrm{dz} / \mathrm{vs} / \mathrm{dz} /$} & $\mathrm{dz} \Lambda \mathrm{r}$ & 'fever' \\
\hline & $\mathrm{dz} \mathrm{z}^{\mathrm{h}} \Lambda \mathrm{r}$ & 'placenta' \\
\hline \multicolumn{3}{|l|}{ Nasals } \\
\hline \multirow[t]{2}{*}{$/ \mathrm{m} / \mathrm{vs} / \mathrm{n} /$} & ma-na & 'an equal measurement of a plate' \\
\hline & na-na & 'mother's father' \\
\hline \multirow[t]{2}{*}{$/ \mathrm{n} / \mathrm{vs} / \mathrm{n} / \mathrm{swan}$} & & 'gold' \\
\hline & swan & 'to mimic or to joke' \\
\hline \multicolumn{3}{|c|}{ Alveolar trill vs lateral } \\
\hline \multirow[t]{2}{*}{ /r/ vs /l/ swar } & & 'voice' \\
\hline & swal & 'to glide' \\
\hline \multicolumn{3}{|c|}{ Bilabial vs palatal approximants } \\
\hline \multirow[t]{2}{*}{ /w/ vs /y/ } & $1 \Lambda$ tu-wa & ‘dumb’ \\
\hline & lpti-ya & 'a steel jug' \\
\hline
\end{tabular}

There are some sounds such as bilabial, alveolar voiced aspirated nasal $/ \mathrm{m}^{\mathrm{h}}$, $\mathrm{n}^{\mathrm{h}} /$, alveolar voiced aspirated lateral $/ 1^{\mathrm{h}} /$ and alveolar voiced aspirated trill $/ \mathrm{r}^{\mathrm{h}} /$ are the residual sounds in Sonaha language. These sounds are found mostly in Tharu words but also in a few Sonaha words as well. Therefore, these sounds are either the innovations due to the influence of other languages or the residual sounds due to the process of sound change.

These sounds are illustrated below in these examples:

$\begin{array}{lll}/ \mathrm{n}^{\mathrm{h}} / & \mathrm{p} \Lambda \mathrm{rn}^{\mathrm{h}} \mathrm{a} & \text { 'to read' } \\ & \mathrm{c}^{\mathrm{h}} \Lambda \mathrm{mn}^{\mathrm{h}} \mathrm{a} & \begin{array}{l}\text { 'to touch' } \\ / \mathrm{r}^{\mathrm{h}} /\end{array} \\ & \begin{array}{l}\mathrm{kumr}_{\mathrm{h}} \mathrm{a} \\ \mathrm{p} \Lambda \mathrm{r}^{\mathrm{h}} \Lambda \mathrm{l}\end{array} & \begin{array}{l}\text { 'pumpkin' } \\ / \mathrm{l}^{\mathrm{h}} /\end{array} \\ \mathrm{p}^{\mathrm{h}} \text { ill }^{\mathrm{h}} \mathrm{a} & \text { 'thigh' }\end{array}$

Full text of this article can be downloaded from www.craiaj.com and www.nepjol.info 


$$
\begin{aligned}
& \operatorname{cul}^{\mathrm{h}} \mathrm{i} \quad \text { 'a small oven' } \\
& / \mathrm{m}^{\mathrm{h}} / \text { guim }^{\mathrm{h}} \mathrm{a} \quad \text { 'a kind of creeper having yellow fruit' }
\end{aligned}
$$

\section{Syllable structure}

Threre are mainly three basic thoeries of syllable structure: the theory of the flat syllable, the onset-rime theory and the theory of body-coda organization. Of all these theories, the onset-rime is perhaps the most widely accepted one (Kessler \&Treiman, 1997).

According to the onset-rime theory, the vowel groups with the coda to form a constituent called the rime. The rime includes an obligatory part called nucleus and an optional part known as coda. The nucleus is always occupied by the vowel or vowel sequence whereas onset and coda positions are occupied by the consonants.

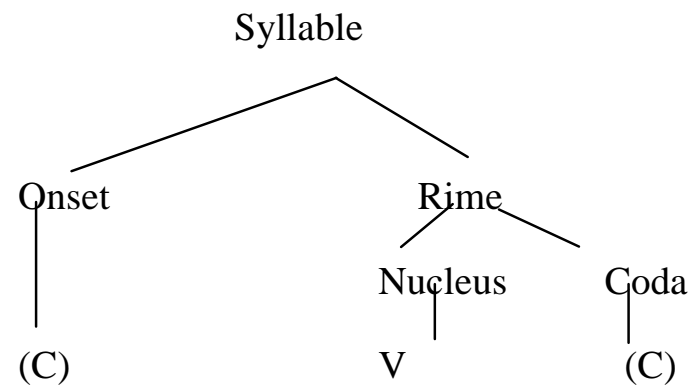

Figure 2. Onset-rime theories of syllable structure

The study revealed six types of syllable structures in Sonaha. They are V, $\mathrm{CV}, \mathrm{VC}, \mathrm{CVC}, \mathrm{CCV}$, and CCVC. The syllable structre and examples are illustrated in the following.

Table 2: Syllable structures

\begin{tabular}{llll}
\hline S.N & Syllables Type & Examples & \\
\hline 1 & V & u & 'he' \\
2 & CV & wa & 'ouch' \\
3 & VC & ak & 'one' \\
4 & CVC & kãs & 'a kind of smooth grass used for making basket' \\
5 & CCV & kya & 'what' \\
6 & CCVC & $k^{\mathrm{h}}$ way & 'a kind of hand made bamboo instrument used \\
& & & for trapping fish' \\
\hline
\end{tabular}

\section{Vowel sequence}


When two or more different vowels appear in a row, and pronounced each one separately with a smooth glide between them is called vowel sequence. A vowel sequence may occur as monophthong and mophthong or monophthong and diphthong together in the same syllable or separating it as two syllables. They look like diphthong in nature. Vowel sequences distributed in Sonaha language are in three positions: word initial, word medial and word final. Word initial vowel sequences are $\Lambda \mathrm{i}, \Lambda \mathrm{u}, \mathrm{ui}$, oi, and ai. Word medial vowel sequences are $\Lambda \mathrm{i}, \Lambda \mathrm{u}$, ui, oi, ai,eu, and ao . And word final vowel sequences are $\Lambda \mathrm{i}, \Lambda \mathrm{u}$, ui,oi,ai and eu. The example is given in the following table:

Table 3: Vowel sequences

\begin{tabular}{|c|c|c|}
\hline Initial & Medial & Final \\
\hline sina'to come' & $\mathbf{k}^{\mathrm{h}} \Lambda$ ina 'to eat' & $\Delta \hat{\mathbf{f} \Lambda \mathbf{i}}$ 'to become' \\
\hline sur 'more' & $\begin{array}{l}\text { nuuch ar 'the back nail of the } \\
\text { cock which is above the finger' }\end{array}$ & $\tilde{\mathbf{a}} \mathbf{k}^{\mathrm{h}_{\mathbf{i}}} \mathbf{b}^{\mathrm{h}} \boldsymbol{\Lambda} \mathbf{u}$ 'eye brow' \\
\hline uiya'a kind of grass' & huina'to be' & tisui 'white and green scorpion' \\
\hline oissne'therefore' & coila'bark of tree' & hoi hoi'ok' \\
\hline \multirow[t]{4}{*}{$\operatorname{air} \boldsymbol{\Lambda} \boldsymbol{\eta}$ 'an ornament worn in ear' } & gaike 'by singing' & osai 'to separate dirt from grain' \\
\hline & deuta'god' & $\mathbf{d z}^{\mathbf{h}} \mathbf{e} \tilde{\mathbf{u}} \mathbf{d} \mathbf{z}^{\mathrm{h}} \mathbf{e} \tilde{\mathbf{u}}^{\text {'an }}$ act of scolding' \\
\hline & $\boldsymbol{\Delta} \mathbf{n} \mathbf{t}^{\mathrm{h}}$ aon 'fifty eight' & \\
\hline & & bau'father' \\
\hline
\end{tabular}

\section{Consonat clusters}

Two or more than two consonats ocurring together is known as consonant cluster. There are two types of consonant clusters in Sonaha. Only initial and medial consonant cluster are found in Sonaha. Final consonant cluster is not found in this language. The initial cluster is maily formed by the sound $/ \mathrm{y} /$ and $/ \mathrm{w} /$ preceeded bythe half-conjoined consonant (halanta) such as $\mathrm{k} / \mathrm{k} / \mathrm{g} / \mathrm{s} / \mathrm{l}+\mathrm{w} / \mathrm{y}$. The medial cluster if formed by mostly doubling the same consonant sound.

Table 4: Consonant clusters

\begin{tabular}{|c|c|}
\hline Initail consonant cluster & Medial consonant cluster \\
\hline kwan 'corner' & $\mathbf{k k k a i s}$ 'twenty one' \\
\hline kyara 'banana' & $\Lambda \mathrm{g} \Lambda \mathrm{nne}$ 'the day before yesterday' \\
\hline $\mathbf{k}^{\mathbf{h}} \mathbf{w a d e}$ 'to dig' & inguri'fingers' \\
\hline $\mathbf{k}^{\mathbf{h}} \mathbf{y} \mathbf{a t}^{\prime}$ farm' & iskul 'school' \\
\hline gwar 'leg' & ubdzna 'to germinate' \\
\hline swan'gold' & killa 'nail' \\
\hline syar'a measurement of one kilogram' & hıgbe 'to stool' \\
\hline
\end{tabular}

Full text of this article can be downloaded from www.craiaj.com and www.nepjol.info 


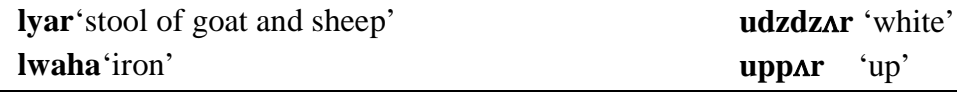

\section{Distributions of the phonemes}

If two sounds of a language replace one with other in the same phonological environment with the change in meaning, those sounds are said to be the phoneme of that language. Following the process of contrastive distribution, Sonaha phonemes have been analyzed using minimal pair in initial, medial and final positions of the words.

\section{Distribution of vowels}

The distributions of the vowels are found in initial, medial and final position. The examples are illustrated in the following table:

Table 5: Distribution of vowels

\begin{tabular}{|c|c|c|c|c|}
\hline $\begin{array}{l}\mathrm{S} . \\
\mathrm{N}\end{array}$ & $\begin{array}{l}\text { Vowe } \\
1\end{array}$ & Initial & Medial & Final \\
\hline 1 & $\Lambda$ & $\begin{array}{c}\boldsymbol{\Lambda g} \mathbf{\Lambda n n e} \text { 'the day before } \\
\text { yesterday' }\end{array}$ & kıdzıra 'eye liner' & gadz 'thunder' \\
\hline 2 & a & ate 'to be' & gahana 'yam' & nana 'mother's father' \\
\hline 3 & $\mathrm{i}$ & Imnik'they' & kuila'left part ofburnt fire' & dai 'mother' \\
\hline 4 & $\mathrm{u}$ & usisa 'pillow' & $\begin{array}{c}\text { guul'a bird which likes to kill } \\
\text { fish' }\end{array}$ & $\begin{array}{l}\text { Knau'main pole of the } \\
\text { house' }\end{array}$ \\
\hline 5 & e & 'heel' & psseri '2.5 kilogram’ & moksne'to me' \\
\hline 6 & o & osne 'in thisway' & $\begin{array}{r}\text { gãrgob } \\
\text { turnip) }\end{array}$ & \\
\hline
\end{tabular}

\section{Distribution of consonants}

To confirm the consonant of Sonaha, the sounds are distributed in all the positions as mentioned below: 
Table 6: Distribution of consonants

\begin{tabular}{|c|c|c|c|c|}
\hline $\begin{array}{l}\mathrm{S} . \\
\mathrm{N}\end{array}$ & $\begin{array}{l}\text { Co } \\
\text { nso } \\
\text { nan } \\
\mathrm{t}\end{array}$ & Initial & Medial & Final \\
\hline 1 & $\mathrm{k}$ & $\begin{array}{l}\text { ksnau 'main pole of } \\
\text { house' }\end{array}$ & niksrna 'to take out' & ak 'one' \\
\hline 2 & $\mathrm{k}^{\mathrm{h}}$ & $\begin{array}{c}\mathbf{k}^{\mathbf{h}} \boldsymbol{\Lambda} \mathbf{b} \boldsymbol{\Lambda} \mathbf{f a} \mathbf{a}^{\text {'a }} \text { type of } \\
\text { watermelon like } \\
\text { vegetable' }\end{array}$ & $\begin{array}{c}\mathbf{b} \mathbf{\Lambda} \mathbf{k k}^{\mathbf{h}} \mathbf{a r i}^{\text {'breadbasket used }} \\
\text { for keeping grain' }\end{array}$ & $\mathrm{d} \mathbf{\Lambda} \mathbf{r k} \mathbf{h}^{\mathbf{h}}$ 'arum' \\
\hline 3 & $\mathrm{~g}$ & 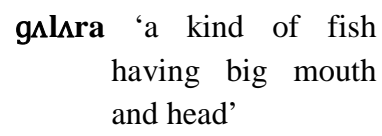 & dignr'narrow road' & $\begin{array}{l}\text { duggi'cutting board for } \\
\text { meat' }\end{array}$ \\
\hline 4 & $g^{h}$ & $\mathbf{g}^{\mathrm{h}} \Lambda \mathbf{n n a}$ 'to wear' & bıg ${ }^{\text {h}}$ uwa 'a tiger' & $\mathbf{d z} \mathbf{z}^{\mathbf{h}} \mathbf{a g}^{\mathbf{h}} \quad$ 'thigh' \\
\hline 5 & $\eta$ & & $\mathbf{b}^{\mathrm{h}} \boldsymbol{\Lambda} \boldsymbol{b} \mathbf{b}^{\mathrm{h}} \boldsymbol{\Lambda} \mathbf{u} \mathbf{s} \mathbf{a}$ 'slow minded' & swan 'to joke' \\
\hline 6 & $\mathrm{c}$ & cیkiya 'grinder' & $\mathbf{k}^{\mathrm{h}} \Delta \mathbf{r c a h a}$ 'extravagant' & $\begin{array}{l}\text { kyãc 'the dead outer } \\
\text { part of the snake } \\
\text { that is changed } \\
\text { regularly' }\end{array}$ \\
\hline 7 & $c^{h}$ & $\operatorname{ch}^{\mathrm{h}}$ aw $\Delta \mathbf{s}^{\text {‘son’ }}$ & $\begin{array}{l}\text { ps } \mathbf{c}^{\mathrm{h}} \text { ela 'a thick silver ring } \\
\text { worn on the wrist or worn } \\
\text { behind the main } \\
\text { bangle' }\end{array}$ & 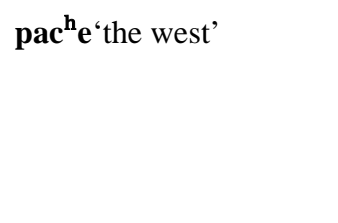 \\
\hline 8 & $\mathrm{dz}$ & dzl $\mathbf{l}_{\mathbf{M}}$ 'birth' & mıdzuri 'work of labour' & gadz 'thunder' \\
\hline 9 & $\mathrm{dz}^{\mathrm{h}}$ & $\mathbf{d z}^{\mathrm{h}} \mathbf{b} \boldsymbol{\Lambda} \mathbf{r a}$ 'a basket' & $\begin{array}{l}\text { mandz }{ }^{\mathrm{h}} \Lambda \mathbf{l a} \text { 'the second } \\
\text { brother' }\end{array}$ & $\operatorname{god} \mathbf{z}^{\mathbf{h}_{\mathbf{i}}}$ 'pocket' \\
\hline 10 & $\mathrm{t}$ & $\begin{array}{l}\text { tıriyã 'a kind of thick } \\
\text { and hollow silver ring } \\
\text { worn round the arm' }\end{array}$ & $\begin{array}{l}\text { petar 'an object made by } \\
\text { grass to keep new clothes on } \\
\text { it' }\end{array}$ & pyat 'stomach' \\
\hline
\end{tabular}

Full text of this article can be downloaded from www.craiaj.com and www.nepjol.info 
tortoise or snail'

12 d dabi'wooden $\log$ '

$13 \mathrm{~d}^{\mathrm{h}} \quad \mathrm{d}^{\mathrm{h}} \mathbf{y a n}$ 'tall'

14 t tadza 'fresh'

$15 \mathrm{t}^{\mathrm{h}} \quad \mathbf{t}^{\mathrm{h}} \boldsymbol{\Lambda}$ riya 'plate'

$16 \mathrm{~d}$

duriya 'small pieces of gudura 'fox' grain'

$17 \mathrm{~d}^{\mathrm{h}}$

d $^{\text {himuri'a bamboo object }}$ used for catching fish'

18 n n⿳亠幺⿲丿 'finger nail' $\mathrm{n}^{\mathrm{h}}$

19 p pstuihya 'daughter in law'

$20 \quad \mathrm{p}^{\mathrm{h}} \quad \mathbf{p}^{\mathrm{h}} \Lambda$ tik 'clear water'

21 b barau 'a part of stone and sand separated for processing gold'

$22 \mathrm{~b}^{\mathrm{h}} \quad \mathbf{b}^{\mathrm{h}} \boldsymbol{\Lambda} \operatorname{tar} \boldsymbol{\Lambda} \mathbf{s}^{\text {'h }}$ husband'

$23 \mathrm{~m}$

mss 'mosquito'

$\mathrm{m}^{\mathrm{h}}$ maize plant' husband' sındaha'bad-tempered'

$\mathbf{k} \Lambda \mathbf{m d}{ }^{\mathrm{h}} \Lambda$ anya 'slave girl'

$\mathbf{k}^{\mathrm{h}} \mathbf{\Lambda} \mathbf{t} \mathbf{l a}$ 'a left part of cooked bate 'folk tale' raw materials of alcohol'

$\mathbf{p} \Lambda \mathbf{t}^{\mathrm{h}} \Lambda \mathbf{r a}$ 'stone'

sokt $^{\text {ha }}$ 'dried'

gyadã 'a ball'

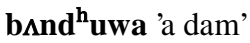

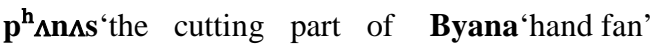

Sen ${ }^{\mathbf{h}}$ 'scales of fish'

Ipar'your own side of river'

kwãp'a kind of measurement with palm, a folding of a hand palm'

$\mathbf{p}^{\mathrm{h}} \mathbf{u} \mathbf{p}^{\mathrm{h}} \mathbf{\Lambda} \mathbf{k} \quad$ 'father's sister's $\mathbf{d z u}_{\mathbf{p}} \mathbf{p}^{\mathrm{h}} \mathbf{e}$ 'whenever'

gn bola 'leaf of arum'

dzalebi 'redcoloured rounded juicy sweet'

$\mathbf{k}^{\mathbf{h}} \mathbf{o b}{ }^{\mathrm{h}} \mathbf{r i}$ 'a small box of clay attached on the wall that is used to store grain'

dzımãwa 'curd' d'im 'slow, dim light' guima 'a kind of creeper having yellow fruits'

Full text of this article can be downloaded from www.craiaj.com and www.nepjol.info 


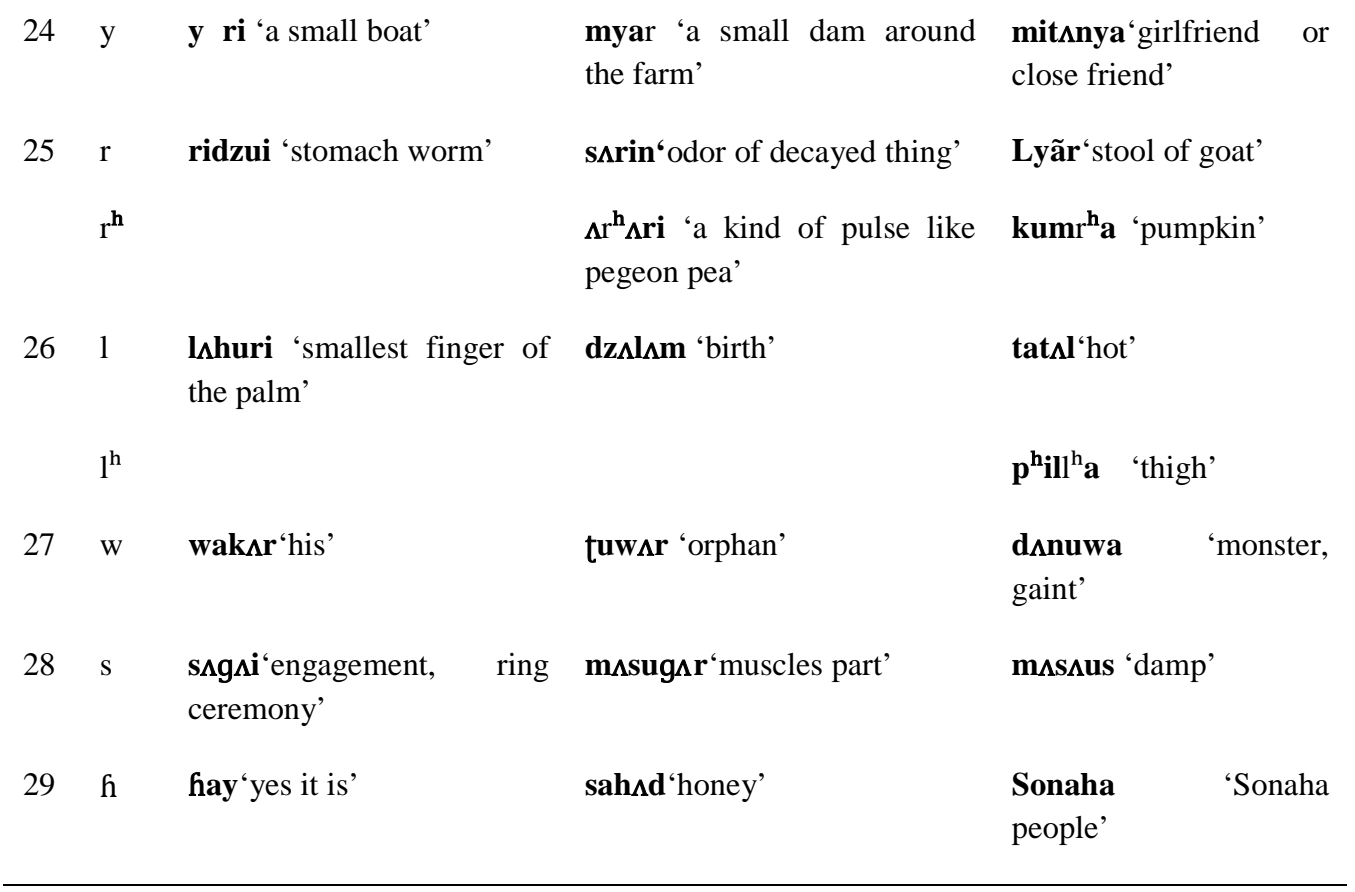

The main objective of the study was to determine the phoneme of Sonaha. After analyzing the collected data, the study confirmed six vowels: / $\Lambda, \mathrm{a}, \mathrm{i}, \mathrm{e}, \mathrm{u}, \mathrm{o}$, twenty nine consonants: $/ \mathrm{k}, \mathrm{k}^{\mathrm{h}}, \mathrm{g}, \mathrm{g}^{\mathrm{h}}, \mathrm{y}, \mathrm{c}, \mathrm{c}^{\mathrm{h}}, \mathrm{dz}, \mathrm{dz} \mathrm{z}^{\mathrm{h}}, \mathrm{t}, \mathrm{t}^{\mathrm{h}}, \mathrm{d}, \mathrm{d}^{\mathrm{h}}, \mathrm{t}, \mathrm{t}^{\mathrm{h}}, \mathrm{d}, \mathrm{d}^{\mathrm{h}}, \mathrm{n}, \mathrm{p}, \mathrm{p}^{\mathrm{h}}$, $\mathrm{b}, \mathrm{b}^{\mathrm{h}}, \mathrm{m}, \mathrm{y}, \mathrm{r}, \mathrm{l}, \mathrm{w}, \mathrm{s}, \mathrm{h} /$; four residual voiced aspirated consonants: / $\mathrm{m}^{\mathrm{h}}, \mathrm{n}^{\mathrm{h}}, \mathrm{l}^{\mathrm{h}}$ and $\mathrm{r}^{\mathrm{h}} /$; six types of syllable structure: $\mathrm{V}, \mathrm{CV}, \mathrm{VC}, \mathrm{CVC}, \mathrm{CCV}, \mathrm{CCVC}$, and seven types of vowel sequences: $/ \Lambda \mathrm{i}, \Lambda \mathrm{u}$, ui, oi, ai,eu, ao /in Sonaha. The distribution of the consonants is also even like that of the vowels. All the consonants excluding residual and $/ \mathrm{y} /$ sounds are found in the word initial, word medial and word final position, but the medial position of the distribution is not even. The consonant cluster within the syllable occurs only in the onset of the syllable. Basic syllable structure in Sonaha language is $(\mathrm{C})(\mathrm{C}) \mathrm{V}(\mathrm{C})$, i.e. $\left(\mathrm{C}^{2} \mathrm{VC}\right)$. The vowel sequence is found in all the position of the word.

\section{Conclusion and implications}

Basing the data analysis on minimal pairs of vowels, consonants, their distributions and the syllable structure, the study determined six vowels and 29 consonants, six 
types of syllable structures, and seven types of vowel sequences. The findings drawn from fifty native speakers data are valid since the population of target native speakers is less, i.e. 1172. The use of interviews, field obserations, questionnaires and FGD for collecting data drew the actual informations. The studywas not based on any hypothesis, however, the findings of phonemes are correspondent to its neighbouring language such as Rana and Dangaura Tharu. The study was limited only in three districts and only fifty native speakers were sampled as population. It has focused only phonological aspects of this language.

Many studies have been done regarding Sonaha socio-culture, economic condition, health, education and language. Since no any studies about Sonaha phoneme and phonology have been done, this study will be the foundation for the Sonaha language researchers or text book writers. The findings are applicable as per the policy of government regarding mother tongue multilingual education, this study will play a vital role in designing the local language curriculum, and writing text books in Sonaha language. However, the findings of my study has limits. The depth study about some other linguistic aspects of this language is still required.

\section{References}

Adhikari, G. P. (2009). Socio-cultural life and livelihood options of Sonaha of Patabhar, Bardiya district. An unpublished M.A. thesis submitted to TU.

American Psychological Association (2010). Publication manual of the American psychological association. Washington, DC: American Psychological Association.

Budha, B. S. (2006). Sonaha jatiko manabshastriya addhayan. Research Journal,1(1),pp. 12-37.

Carr, P. (2013). English phonetics and phonology: An introduction $\left(2^{\text {nd }}\right.$ ed.).WileyBlackwell.

Central Bureau of Statistics (CBS), (2001). Population census report. Kathmandu: Central Bureau of Statistics.

Central Bureau of Statistics, (2012). National population and housing census-2011. Kathmandu: Central Bureau of Statistics, National Planning Commission (NPC). 
Central Bureau of Statistics, (2014). Population monograph of Nepal (Vol. II). Kathmandu: Central Bureau of Statistics, National Planning Commission (NPC).

Chaudhary, M. K. (2013). Language of Saptariya Tharu. A Research Journal of Culture and Society 1 (2).DOI: https://doi.org/10.3126/researcher.v1i2.9885

Chaudhary, A. D., Chaudhary, B. \& Khanal. P. (2018b).Words collection of Sonaha language. A report submitted to Language Commission Nepal.

Chaudhary, A. D., Chaudhary, B. \& Khanal. P. (2019). Linguistic history of Sonaha. A report submitted to Language Commission Nepal.

Chaudhary, B. R. (2020, July 30). Tharu bhasalai manak banaune adhar.

HamarPahura. Retrieved from

https://tihakarilekh.blogspot.com/2020/07/blogpost.html?spref=fb\&fbclid=IwAR1fKZi966jxLnVAEqPDQt5jTnSiTCeXi7L Tb4jt8xWevrQ81yljnNsHQi0

Crystal, D. (2008). A Dictionary of linguistics and phonetics 6th edition. Oxford: Blackwell Publishing.

Dhakal, D.N. (2013). The documentation of the Rana Tharu language. A research report submitted to Nepal Academy, Kathmandu, ms.

Eberhard, D. M., Gary, F. S. \& Charles, D. F. (Eds).(2019). Ethnologue language of world.( $22^{\text {nd }}$ edition).Dalls, Texas: SIL International.Retrieved from https://www.ethnologue.com/language/soi

Eppele, J. W., Lewis, M. P., Regmi, D. R. \& Yadav, Y. P. (Eds). (2012). Ethnologue languages of Nepal. Katmandu: SIL International \& TU Central Department of Linguistics.

G.C. P. (2013). A study on socio-cultural and economic condition of Sonaha. An unpublished M.A. thesis submitted to TU.

Goshain, T. (2013). A study on verbs of harvesting and wedding ceremony in Sonaha, English and Nepali. An unpublished M.Ed thesis submitted to TU.

Gutt, U. (2009). Introduction to English phonetics and phonology (Vol.1). New York: Peter Lang GmbH.

Kessler ,B. \&Treiman, R. (1997). Syllable structure and the distribution of phonemes in English syllables. Journal of Memory and Language, 37(n.n) 295-311.

Retrieved from http://spell.psychology.wustl.edu/SyllStructDistPhon/CVC.html

Full text of this article can be downloaded from www.craiaj.com and www.nepjol.info 
Lohar, G. T. (2008). Sound system for standardization of the Bhojpuri language. Nepalese Linguistics, 23 (n.n).144-156. http://himalaya.socanth.cam.ac.uk/collections/journals/nepling/pdf/Nep_Ling 23.pdf

NFDIN (2020). Dangaura Tharu bhasako varnna nirdharn. NFDIN: Kathmandu.

Roach, P. (2013). English phonetics and phonology: A practical course. UK: CUP.

Saud, M.S. (2010). Foundation of language and linguistics. Kathmandu: MK Publication.

Sonaha Sangh.(2007). Sonaha jatiya parichaya. Patabhar, Bardiya: Nepal Sonaha Sangh.

Sonaha, S. (2018). Sonaha population: A brief study. An unpublished research report submitted to Sonaha Bikas Munch, Bardiya.

Sonaha, S. (2000). Sonahako samkshipta parichaya utpatti ra pesha. An unpublished research report submitted to Sonaha Bikas Munch, Bardiya.

Thakur, G. \& Thakur, I. (2014). A Socio-linguistic survey of Sonaha and Khuna. A report submitted to linguistic survey of Nepal(LinSuN),Central Department of Linguistics, TU: Kathmandu.

Thing, S. J. (2014). The polemics and discourse of conservation in Nepal: A case study of Sonaha Indigenous minorities and Bardia National Park (Doctoral dissertation, Curtin University). Retrieved from https://espace.curtin.edu.au/handle/20.500.11937/912.

Webster, J. D. (1993). A sociolinguistic profile of the Tharu dialects of the western Indo-Nepal Tarai. Kathmandu,ms. Retrieved from https://www.sil.org/system/files/reapdata/53/06/89/530689700207670709021 99092715591816585/silesr2017_013.pdf

Yadava, Y. P. (2014). Language use in Nepal. Government of Nepal, National Planning Commission Secretariat (ed.), Population Monograph of Nepal: Social Demography, 2, 51-72. 